Jurnal KONTEKSTUAL

Volume 01, No. 1, Agustus 2019, pp. 7-17

\title{
PEMANFAATAN KOMPONEN INSTRUMEN TERPADU IPA SEKOLAH DASAR NEGERI TERAKREDITASI A
}

\author{
Agus Purnomo \\ Prodi Pendidikan Guru Sekolah Dasar, Fakultas Keguruan dan Ilmu Pendidikan \\ Universitas Muhadi Setiabudi Brebes, Indonesia \\ e-mail: aguspurnomo.umus@gmail.com
}

\begin{abstract}
ABSTRAK
Penelitian ini bertujuan untuk mendeskripsikan pemanfaatan Komponen Instrumen Terpadu (KIT) IPA pada pembelajaran mapel IPA materi Pesawat Sederhana kelas $V$ di SD $N$ Terakreditasi A se-Kecamatan Ketanggungan. Metode yang digunakan dalam penelitian ini adalah metode deskriptif dengan bentuk penelitian survei. Berdasarkan hasil analisis data, ketersediaan KIT IPA pesawat sederhana di SD N terakreditasi A se-Kecamatan Ketanggungan rata-rata persentase ketersediaan di seluruh sekolah adalah 98,3\%, di kategorikan sangat baik, meliputi: SDN 3, dan SDN 4 sebesar 100\% dan SDN 9 sebesar 95\%. Kondisi KIT IPA pesawat sederhana di SD Negeri terakreditasi A se-Kecamatan Ketanggungan adalah 100\%, di kategorikan sangat baik, meliputi: SDN 9 sebesar 95\%, SDN 3 dan SDN 4 sebesar 100\%. Pemanfaatan KIT IPA di 3 SD Negeri Terakreditasi A se-Kecamatan Ketanggungan dikategorikan "kurang sekali", dan hasil persentasenya sebesar 24\%. Peneliti menyarankan kepada guru-guru yang mengajar mapel IPA agar mengikuti pelatihan bagi guru untuk lebih memanfaatkan KIT IPA yang sudah tersedia agar pembelajaran dapat berjalan secara optimal dan dapat meningkatkan kualitas pembelajaran.
\end{abstract}

Kata Kunci: KIT, Ilmu Pengetahuan Alam.

\begin{abstract}
This study aims to describe the utilization of the Integrated Instrument Component (KIT) of Natural Sciences in the learning of natural science subject matter of Simple V-grade class V at $S D N$ Accredited A in Ketanggungan District. The method used in this research is descriptive method with survey research. Based on the results of data analysis, the availability of KIT IPA of simple planes in SD N is accredited A in Ketanggungan District. SDN 9 is 95\%. The condition of a simple aircraft KIT for IPA in accredited A Public Schools in Ketanggungan District is 100\%, categorized as very good, including: SDN 9 by 95\%, SDN 3 and SDN 4 by 100\%. Utilization of Natural Science KIT in 3 Accredited A Elementary Schools in Ketanggungan District is categorized as "very poor", and the percentage yield is 24\%. The researcher suggests to the teachers who teach natural science subjects to attend training for teachers to better utilize the natural science KIT that is already available so that learning can run optimally and can improve the quality of learning.
\end{abstract}

Keyword: KIT, Natural Science.

\section{PENDAHULUAN}

Pembelajaran berkualitas adalah pembelajaran yang mengintegrasikan bahan pelajaran, strategi, media pembelajaran, siswa dan guru. Meningkatnya kualitas pendidikan tergantung pada pemahaman guru dalam melaksanakan tugasnya di 
Jurnal KONTEKSTUAL, Volume 1, No. 1, Agustus 2019, pp. 7-17

sekolah dan pemahaman terhadap pentingnya media pembelajaran [1].

Terinspirasi dari Piaget dalam (Zainal Aqib: 2013), yang berpendapat bahwa aspek penting yang ada hubungannya dengan perkembangan kognitif diantaranya adalah pengalaman fisik, yaitu anak harus mempunyai pengalaman dengan benda dan stimulus dalam lingkungan tempat ia bereaksi terhadap benda tersebut. Lingkungan kelas dapat menjadi ajang kegiatan dan kreativitas yang menyebabkan pembelajaran terjadi dengan siswa yang menjadi pusat pembelajarannya. Lingkungan kelas dan ketersediaan media pembelajaran akan mempengaruhi kemampuan siswa dalam menerima materi pelajaran [2].

Dengan demikian siswa akan membangun pengetahuan sendiri melalui media yang dibuat dan dimanfaatkan oleh gurunya dalam proses pembelajaran [3].

Kosasih Djahiri (2007: 64) menyatakan bahwa "Kualitas proses kegiatan belajar siswa sangat menentukan kualitas dan kuantitas hasil kegiatan belajar siswa, proses kegiatan belajar siswa akan lebih mudah, lancar dan sukses dengan bantuan aneka media dan sumber belajar" [4].

Berdasarkan hasil observasi kelas terhadap proses pembelajaran Ilmu Pengetahuan Alam kelas V di sekolah yang diamati, guru tidak memanfaatkan KIT IPA dalam pembelajaran. Guru hanya menggunakan media pembelajaran yang berupa papan tulis, spidol dan buku paket, sehingga pembelajarannya hanya sekedar lihat, catat dan dengar [5].

Sedangkan menurut Mendiknas (2006) yang tertuang di dalam Permendiknas No. 22 Tahun 2006 menyatakan bahwa Ilmu Pengetahuan Alam merupakan hasil kegiatan manusia berupa pengetahuan, gagasan, dan konsep yang terorganisasi tentang alam sekitar, yang diperoleh dari pengalaman melalui serangkaian proses ilmiah antara lain penyelidikan, penyusunan dan pengujian gagasangagasan [6].

Sehingga dapat disimpulkan bahwa pembelajaran Ilmu Pengetahuan Alam yang seharusnya dilaksanakan di kelas $\mathrm{V}$ pada materi pesawat sederhana menggunakan metode pembelajaran eksperimen dengan menggunakan KIT IPA dengan tujuan untuk menanamkan konsep-konsep IPA kepada siswa melalui serangkaian kegiatan ilmiah [7].

Berdasarkan fakta ketika peneliti menggantikan guru kelas $\mathrm{V}$ mengajar IPA di salah satu Sekolah Dasar Negeri di Kecamatan Ketanggungan, peneliti menggunakan KIT IPA sebagai media dalam pembelajaran, ternyata respon siswa sangat antusias dan aktif dalam mengikuti pembelajaran dan peneliti yakin bahwa pemanfaatan KIT IPA sebagai media pembelajaran Ilmu Pengetahuan Alam pada materi pesawat sederhana di kelas V di Sekolah Dasar Negeri Terakreditasi A Kecamatan Ketanggungan memiliki peran yang sangat penting dalam proses pembelajaran.

KIT IPA sebagai media pembelajaran Ilmu Pengetahuan Alam merupakan fungsi untuk meningkatkan kualitas proses belajar mengajar, karena pada umumnya pemahaman belajar siswa dengan menggunakan media akan tahan lama sehingga kualitas pembelajaran memiliki nilai yang tinggi $[8]$.

Berdasarkan uraian di atas,
peneliti merasa tertarik untuk
melakukan penelitian yang berjudul
"Pemanfaatan Komponen Instrumen 
Jurnal KONTEKSTUAL

Volume 01, No. 1, Agustus 2019, pp. 1-6

Terpadu IPA Sekolah Dasar Negeri Terakreditasi A.”

\section{KAJIAN TEORI}

Suatu tantangan bagi guru IPA untuk mengembangkan Pembelajaran IPA/sains yang mampu memberikan wawasan berpikir dan mengembangkan kemampuan kerja ilmiah siswa. Oleh sebab itu semestinya siswa diberi kesempatan untuk berinteraksi langsung dengan obyek belajar, mengamati, mengembangkan pertanyaan, menghubungkan fakta dengan sumber pengetahuan, mengambil kesimpulan dan mengkomunikasikan alternatif solusi untuk perbaikannya. Mereka semestinya diberi kesempatan berinkuiri untuk mengembangkan keterampilan, pengetahuan dan sikap saat pembelajaran berlangsung di dalam kelas maupun di luar kelas [9].

Berdasarkan SKL dalam kurikulum 2013, keterampilan proses yang dimaksud adalah mengamati, menanya, mencoba, mengolah, menyaji, menalar dan mencipta, sedangkan keterampilan abstraknya membaca, menulis, menghitung, menggambar dan mengarang (Permendikbud no 61 tahun 2014). Hal tersebut selaras dengan pembelajaran inkuiri yang menekankan pada kerja ilmiah yaitu: mengumpulkan informasi, merumuskan masalah, membuat hipotesis, merumuskan variabel, memprediksi, menghitung, membuattabel, grafik, menyimpulkan, dan mengkomunikasikan.

Pembelajaran Ilmu Pengetahuan Alam (IPA) di Sekolah Dasar (SD) pada kurikulum tahun 2013 terdapat beberapa perubahan antara lain: konsep pembelajarannya dikembangkan sebagai mata pelajaran integrative science atau "IPA Terpadu" bukan sebagai pendidikan disiplin ilmu. Konsep keterpaduan ini ditunjukkan dalam
Kompetensi Inti (KI) dan Kompetensi Dasar (KD) pembelajaran IPA yaitu di dalam satu KD sudah memadukan konsep-konsep IPA dari bidang ilmu biologi, fisika, dan ilmu pengetahuan bumi dan antariksa (IPBA) [10].

Oleh karena itu guru dituntut dapat membuat dan mengembangkan perangkat pembelajara IPA secara terpadu dalam berbagai materi pelajaran IPA. Model pembelajaran IPA terpadu memungkinkan terjadinya proses kegiatan belajar mengajar (KBM) yang lebih efisien dan efektif. Dengan pembelajaran IPA terpadu, materi-materi tidak akan saling tumpang-tindih nantara satu dengan yang lain sebagaimana apabila diajarkan secara terpisah-pisah. Selain itu waktu pembelajaran dapat dikurangi untuk kegiatann lapangan misalnya praktikum.

Penguasaan IPA melalui pembelajaran secara teoritis sangat ditentukan oleh kemampuan dan kreatifitas siswa dalam menguasai keterampilan proses sains. Siswa yang mempunyai keterampilan proses bagus maka prestasi akademiknya juga bagus. Carin dan Sund (1993) mendefinisikanm sains sebagai "pengetahuan yang sistematis dan tersusun secara teratur, berlaku umum (universal), dan berupa kumpulan data hasil observasi dan eksperimen" [11].

Merujuk pada pengertian IPA, maka dapat disimpulkan bahwa hakikat IPA meliputi empat unsur utama yaitu: (1) sikap: rasa ingin tahu tentang benda, fenomena alam, mahluk hidup, serta hubungan sebab-akibat yang dapat dipecahkan melalui prosedur yang benar; sains bersifat open ended; (2) proses: prosedur pemecahan masalah melalui metode ilmiah; metode ilmiah meliputi penyusunan hipotesis, perancangan eksperimen atau percobaan, evaluasi, pengukuran, dan 
penarikan kesimpulan; (3) produk: berupa fakta, prinsip, teori, dan hukum; (4) aplikasi: penerapan metode ilmiah dan konsep sains dalam kehidupan sehari-hari. Keempat unsur itu merupakan ciri sains yang utuh yang sebenarnya tidak dapat dipisahkan satu sama lain. Oleh karena itu untuk mencapai produk pembelajaran IPA yang optimal, siswa di samping mampu menguasai konsep-konsep IPA, juga perlu menguasai keterampilan proses sains dan memiliki sikap/karakter seorang saintis [12].

Untuk itulah maka dipandang sangat perlu suatu perangkat pembelajaran IPA terpadu yang dapat membawa siswa memperoleh pengalaman belajar secara langsung dengan situasi alam sekitarnya guna meningkatkan hasil belajar dan keterampilan proses sains serta dapat mengembangkan sikap dan karakter. Guru IPA dituntut untuk mampu mendesain pembelajaran yang baik, ditunjang dengan pemilihan metode yang tepat sesuai dengan karakter materi. Dalam benaknya selalu berpikir tentang apa yang harus diajarkan dan bagaimana cara mengajarkan hal itu dengan metode terbaik [13].

\section{METODE PENELITIAN}

Metode penelitian yang digunakan adalah metode deskriptif dengan bentuk rancangan penelitian yang digunakan adalah survei. Subjek penelitian ini adalah guru kelas $\mathrm{V}$ yang mengajar mata pelajaran IPA di Sekolah Dasar Negeri Terakreditasi A seKecamatan Ketanggungan yang berjumlah 3 orang [14].

Teknik pengumpulan data yang digunakan yaitu teknik observasi langsung, teknik komunikasi langsung dan teknik studi dokumenter. Sedangkan alat pengumpul data yang dikumpulkan antara lain: lembar observasi, pedoman wawancara dan dokumen berupa data yang diperlukan dalam penelitian. Dalam menjawab sub masalah 1, 2, dan 3 peneliti menggunakan teknik analisis data berupa lembar observasi yang kemudian dihitung presentasenya dengan menggunakan rumus presentase. Setelah itu hasil perhitungannya diinterpretasikan menjadi bentuk kualitatif yang dideskripsikan apa adanya [15].

Untuk mengetahui presentase klasifikasi dari ketersediaan, kondisi dan cara pemanfaatan KIT IPA pesawat sederhana pada kelas V Sekolah dasar Negeri terakreditasi A se-Kecamatan Ketanggungan, data hasil lembar observasi dihitung dengan menggunakan rumus presentase.

Adapun rumus persentase menurut Muhammad Ali (2005: 184) yaitu sebagai berikut:

$$
\%=\frac{n}{N} \times 100
$$

Keterangan:

$\begin{array}{ll}\% & =\text { Hasil presentase. } \\ \mathrm{n} & =\text { Jumlah skor alternatif. } \\ \mathrm{N} & =\text { Jumlah skor maksimal sampel }\end{array}$ [16].

Hasil dari data lembar observasi dihitung menggunakan rumus rata-rata yang dikemukakan oleh Nana Sudjana (2011: 109) yaitu sebagai berikut: $X=\frac{\sum x}{N}$

Keterangan:

$\mathrm{X}=$ Rata-rata hitung.

$\begin{array}{ll}\sum_{\mathrm{N}} \mathrm{x} & =\text { Jumlah Seluruh skor. } \\ & =\text { Jumlah item. }\end{array}$

Setelah mengetahui hasil ratarata persentase data lembar observasi, selanjutnya adalah menentukan kriteria tentang pemanfaatan KIT IPA dalam 
pembelajaran Ilmu Pengetahuan Alam materi pesawat sederhana pada kelas $\mathrm{V}$ Sekolah Dasar Negeri terakreditasi A se-Kecamatan Ketanggungan yang dapat dilakukan dengan menentukan persentase skor ideal (skor maksimum) $=100 \%$. Kemudian menentukan persentase skor terendah (skor minimum) $=0 \%$ Kemudian Menentukan range $=100-0=100$ dan interval yang dikehendaki. Akhirnya menentukan lebar interval $(100 / 5=20)$.

Berdasarkan perhitungan di atas, maka range persentase dan kriteria kualitatif dapat di tetapkan tolok ukur sebagai berikut [17]:
1. $80-100 \%$
= Baik Sekali.
2. $70-79 \%$
$=$ Baik.
3. $60-69 \%$
= Cukup.
4. $50-59 \%$
= Kurang.
5. $0-49 \%$
$=$ Kurang Sekali.

Prosedur yang dilakukan dalam penelitian ini adalah sebagai berikut: Pertama peneliti melakukan observasi ke Sekolah Dasar Negeri untuk menemukan masalah. Setelah menemukan masalah, peneliti merumuskan masalah penelitian. Kemudian dilanjut dengan mencari sumber data yang dibutuhkan dalam suatu penelitian. Kemudian peneliti menyusun instrumen penelitian dan melakukan validitas instrumen penelitian. Setelah persiapan dilakukan, peneliti melakukan penelitian. Tahap selanjutnya adalah melakukan analisis data dan menganalisis hasil penelitian. Akhirnya peneliti menarik kesimpulan dari hasil penelitian [18].

\section{HASIL DAN PEMBAHASAN}

Penelitian ini bertujuan untuk mendeskripsikan pemanfaatan Komponen Instrumen Terpadu IPA pada pembelajaran Ilmu Pengetahuan Alam materi Pesawat Sederhana kelas V di Sekolah Dasar Negeri
Terakreditasi A se-Kecamatan Ketanggungan. Metode yang digunakan dalam penelitian ini adalah metode deskriptif dan bentuk penelitian ini adalah survei. Subjek penelitian ini adalah guru kelas $\mathrm{V}$ yang mengajar mata pelajaran IPA di Sekolah Dasar Negeri Terakreditasi A se-Kecamatan Ketanggungan berjumlah 3 orang [19].

Penelitian ini terdiri dari dua tahapan, yaitu: Pertama, tahap persiapan yaitu menyusun alat atau instrumen penelitian, dan mengurus surat ijin penelitian. Kedua, tahap pelaksanaan yaitu Penyerahan surat izin penelitian ke seluruh Sekolah Dasar Negeri Terakreditasi A se-Kecamatan Ketanggungan pada tanggal 20 Januari s/d 20 Februari 2018.

Peneliti melakukan observasi ketersedian dan kondisi KIT IPA di Sekolah Dasar Negeri Terakreditasi A se-Kecamatan Ketanggungan pada tanggal 20-22 Januari 2018, yaitu melakukan observasi kelas pada proses pembelajaran Ilmu Pengetahuan Alam materi pesawat sederhana pada siswa kelas V Sekolah Dasar Negeri Terakreditasi A se-Kecamatan Ketanggungan dan melakukan wawancara kepada guru mata pelajaran Ilmu Pengetahuan Alam kelas V Sekolah Dasar Negeri Terakreditasi A se-Kecamatan Ketanggungan.

Hasil dari penelitian ini diperoleh dari pengumpulan data hasil observasi dan wawancara langsung tentang pemanfaatan KIT IPA dalam pembelajaran Ilmu Pengetahuan Alam materi pesawat sederhana pada kelas $\mathrm{V}$ Sekolah Dasar Negeri terakreditasi A se-Kecamatan Ketanggungan. Meliputi ketersediaan KIT IPA Pesawat Sederhana pada kelas V, kondisi KIT IPA pesawat sederhana pada kelas $\mathrm{V}$ dan cara pemanfaatan KIT IPA pesawat sederhana pada kelas V. 
Jurnal KONTEKSTUAL, Volume 1, No. 1, Agustus 2019, pp. 7-17

Berdasarkan observasi kelas yang dilakukan di SD N 3 Ketanggungan pada tanggal 20 Januari 2018, peneliti mendapatkan hasil persentase sebesar 36\% sehingga dikategorikan "Kurang Sekali". Hal ini dibuktikan dengan data dan informasi bahwa guru tersebut kurang memanfaatkan KIT IPA SEQIP pada pembelajaran Ilmu Pengetahuan Alam khususnya materi pesawat sederhana. Selain itu, guru tersebut kurang mempersiapkan materi yang akan di ajarnya dengan menggunakan KIT IPA SEQIP, sehingga guru tersebut selalu mengulang materi sampai waktu pembelajaran selesai [20].

Kondisi pembelajaran di dalam kelas ditemukan rata-rata murid sudah mampu membedakan jenis pesawat sederhana, walaupun di tengah-tengah pembelajaran murid sudah mulai sibuk dengan aktifitasnya masing-masing tanpa memerhatikan guru yang sedang menjelaskan di depan kelas. Kendala yang ditemukan guru dalam proses pembelajaran adalah guru belum begitu terampil dalam menggunakan KIT IPA SEQIP.

Selanjutnya observasi kelas yang dilakukan di SD N 9 Ketanggungan pada tanggal 21 Januari 2018, peneliti mendapatkan hasil persentase sebesar $18 \%$ sehingga dikategorikan "Kurang Sekali". Hal tersebut dibuktikan dari data dan informasi bahwa guru tersebut tidak memanfaatkan KIT IPA SEQIP dalam pembelajaran Ilmu Pengetahuan Alam materi pesawat sederhana. Guru tersebut hanya menggunakan benda atau barang-barang yang dibawa dari rumah sebagai contoh dalam pembelajaran. Kondisi pembelajaran di kelas ditemukan rata-rata murid sudah bisa mengelompokkan jenis-jenis pesawat sederhana dan manfaat pesawat sederhana di kehidupan sehari-hari melalui kuis cepat berbonus yang disiapkan oleh guru tersebut [21].
Kemudian observasi kelas yang terakhir dilakukan adalah di SD $\mathrm{N} 4$ Ketanggungan pada tanggal 21 Januari 2018, peneliti mendapatkan hasil persentase sebesar $18 \%$ sehingga dikategorikan "Kurang Sekali". Hal tersebut dibuktikan dengan data dan informasi bahwa guru tersebut tidak memanfaatkan KIT IPA SEQIP pada pembelajaran Ilmu Pengetahuan Alam materi pesawat sederhana. Kendala yang dihadapi oleh guru antara lain: guru kurang memahami cara penggunaan KIT IPA SEQIP Pesawat Sederhana, sehingga guru lebih baik meminta murid membawa alat-alat yang mudah dibawa untuk dijadikan contoh pada proses pembelajaran.

Berdasarkan hasil temuan observasi kelas pada 3 Sekolah Dasar Negeri Terakreditasi A se-Kecamatan Ketanggungan rata-rata "kurang sekali" memanfaatkan KIT IPA dalam pembelajaran Ilmu Pengetahuan Alam materi pesawat sederhana dengan hasil persentasenya sebesar $24 \%$.

Pembahasan hasil penelitian diperoleh dari hasil observasi dan wawancara langsung tentang pemanfaatan KIT IPA dalam pembelajaran Ilmu Pengetahuan Alam materi pesawat sederhana kelas $\mathrm{V}$ Sekolah Dasar Negeri terakreditasi A se-Kecamatan Ketanggungan.

Sebelum melakukan suatu penelitian, peneliti mempersiapkan halhal yang berhubungan dengan penelitian, dan bertujuan untuk mendapatkan hasil penelitian yang akurat serta sesuai dengan keadaan tempat penelitian, maka peneliti melakukan beberapa langkah-langkah sebagai berikut:

1. Menyusun Alat/Instrumen Penelitian

Alat-alat dalam penelitian ini adalah lembar observasi, pedoman wawancara dan angket tentang ketersedian, kondisi dan pemanfaatan 
komponen instrumen terpadu (KIT) IPA dalam pembelajaran Ilmu Pengetahuan Alam materi pesawat sederhana kelas V Sekolah Dasar Negeri Terakreditasi A seKecamatan Ketanggungan dengan langkah-langkah sebagai berikut :

a. Membuat Lembar Observasi Lembar observasi digunakan untuk mendapatkan data tentang ketersedian dan kondisi KIT IPA, serta pemanfaatan KIT IPA dalam pembelajaran Ilmu Pengetahuan Alam materi pesawat sederhana kelas V Sekolah Dasar Negeri Terakreditasi A se-Kecamatan Ketanggungan.

b. Menyusun Pertanyaan untuk Wawancara

\begin{tabular}{lr}
\multicolumn{2}{c}{ Menyusun panduan } \\
wawancara bertujuan \\
pertanyaan-pertanyaan
\end{tabular}
diajukan tidak keluar dari konteks penelitian. Pertanyaan dalam panduan wawancara berjumlah 10 butir. Penggunaan wawancara dalam penelitian ini bertujuan untuk menghimpun data-data yang belum lengkap dari perolehan data melalui lembar observasi [22].

2. Mengurus Surat Izin

Surat izin penelitian diperlukan untuk memberikan keterangan dan penguatan tentang pelaksanaan penelitian. Setelah melakukan seminar desain penelitian pada tanggal 19 Desember 2017 dan menyerahkan perbaikan hasil desain penelitian pada tanggal 16 Januari 2018, Program Studi Pendidikan Guru Sekolah Dasar mengeluarkan surat pengantar kepada Pembantu Dekan I Fakultas Keguruan Dan Ilmu Pendidikan Universitas Muhadi Setiabudi nomor: 482/ UMUS 22.6/ DT/ 2018 tanggal 16 Januari 2018.
Surat permohonan bantuan riset tersebut diajukan kepada Kepala UPTD kecamatan Ketanggungan kabupaten Brebes. Kemudian Kepala UPTD kecamatan Ketanggungan mengeluarkan surat izin riset dengan Nomor: 420/ 073/ DIK.A/2018 dengan tembusan disampaikan kepada Kepala Sekolah Dasar Negeri Terakreditasi A se-Kecamatan Ketanggungan dan dosen yang bersangkutan.

Setelah persiapan penelitian yang mencakup persyaratan administrasi dan alat pengumpul data yang diperlukan sudah selesai, maka peneliti melaksanakan penelitian sebagai berikut: Penyerahan surat izin penelitian ke seluruh Sekolah Dasar Negeri Terakreditasi A sekecamatan Ketanggungan pada tanggal 17 dan 18 Januari 2018.

Kemudian peneliti melakukan observasi ketersedian dan kondisi KIT IPA di Sekolah Dasar Negeri Terakreditasi A se-kecamatan Ketanggungan pada tanggal 20-22 Januari 201, yang bersamaan dengan pelaksanaan observasi kelas pada proses pembelajaran Ilmu Pengetahuan Alam materi pesawat sederhana pada siswa kelas $\mathrm{V}$ Sekolah Dasar Negeri Terakreditasi A se-Kecamatan Ketanggungan.

Kemudian peneliti melakukan wawancara kepada guru mata pelajaran Ilmu Pengetahuan Alam kelas V Sekolah Dasar Negeri Terakreditasi A se-Kecamatan Ketanggungan.

Penelitian dimulai pada tanggal 25 Januari s/d 20 Februari 2018. Setelah data yang diperoleh sudah lengkap, maka langkah terakhir adalah perhitungan data.

3. Hasil Wawancara

Wawancara dilakukan sebagai penunjang data yang kurang lengkap 
Jurnal KONTEKSTUAL, Volume 1, No. 1, Agustus 2019, pp. 7-17

pada observasi kelas. Wawancara dilakukan kepada guru mata pelajaran yang bersangkutan dan dilakukan setelah selesai melakukan observasi kelas agar wawancara yang dilaksanakan lebih efektif dan efisien [23].

Wawancara dilakukan pada 3 orang Guru kelas V yang mengajar mata pelajaran Ilmu Pengetahuan Alam di Sekolah Dasar Negeri Terakreditasi A se-Kecamatan Ketanggungan. Peneliti mendapatkan beberapa informasi mengenai ketersediaan dan kondisi KIT IPA yang sudah baik di Sekolah masingmasing, walaupun di salah satu Sekolah tersebut ada beberapa item KIT pesawat sederhana yang kurang lengkap di karenakan hilang.

Untuk pemanfaatan KIT IPA dalam pembelajaran Ilmu Pengetahuan Alam materi pesawat sederhana pada umumnya guru kurang sekali memanfaatkan KIT IPA, ketika dalam pembelajaran guru cenderung lebih memilih alat-alat rumah tangga yang sudah jelas fungsi dan manfaatnya dalam kehidupan sehari-hari yang bisa langsung di contohkan kegunaannya langsung kepada siswa [24].

Berikut ini adalah pembahasan mengenai ketersediaan, kondisi, dan cara pemanfaatan KIT IPA Pesawat Sederhana pada Kelas V.

a. Ketersediaan KIT IPA Pesawat Sederhana Kelas V

KIT IPA di sekolah merupakan salah satu faktor penting bagi warga sekolah terutama bagi guru dan peserta didik yang dapat membantu proses pembelajaran. KIT IPA merupakan salah satu sumber belajar yang sangat efektif dalam membantu guru mengajar serta membantu peserta didik dalam menerima pelajaran. Ketersediaan KIT IPA sangat penting keberadaannya di sekolah.

Berdasarkan penelitian yang telah dilakukan melalui lembar observasi ketersediaan KIT IPA, diketahui bahwa rata-rata persentase ketersediaan KIT IPA dalam pembelajaran Ilmu Pengetahuan Alam materi pesawat sederhana kelas V Sekolah Dasar Negeri terakreditasi A sekecamatan Ketanggungan adalah sebesar 98,3\% dengan kriteria baik sekali. Dari ke-3 sekolah tersebut yang ketersediaan KIT IPA pesawat sederhana yang masuk kategori baik sekali ada sebanyak 3 sekolah yaitu SD N 9 Ketanggungan dengan persentase sebesar 95\%, SD N 3 dan SD N 4 Ketanggungan dengan persentase sebesar $100 \%$.

Hal ini terjadi karena sekolah-sekolah tersebut terdapat ketersediaan KIT IPA SEQIP yang lengkap dan memadai. Dari persentase ketersediaan KIT IPA pesawat sederhana tersebut dan di dukung oleh hasil wawancara terhadap guru mata pelajaran Ilmu Pengetahuan Alam bahwa ketersediaan KIT IPA di masingmasing sekolah sudah sangat baik dan memadai.

b. Kondisi KIT IPA Pesawat Sederhana Kelas V

Selain ketersediaan KIT IPA yang sangat penting, kondisi KIT IPA juga harus baik. Kondisi KIT IPA yang baik akan mempermudah guru dalam menjelaskan materi pelajaran kepada peserta didik. Hasil dari penelitian yang peneliti dapatkan tentang kondisi KIT IPA Pesawat Sederhana kelas V melalui lembar 
observasi kondisi KIT IPA dalam pembelajaran Ilmu Pengetahuan Alam materi pesawat sederhana di kelas $\mathrm{V}$, diperoleh hasil rata-rata persentase kondisi KIT IPA dalam pembelajaran Ilmu Pengetahuan Alam materi pesawat sedehana kelas V Sekolah Dasar Negeri terakreditasi A se-Kecematan Ketanggungan adalah sebesar 100\% dalam kondisi layak.

Dari ke 3 sekolah yang kondisi KIT IPA pesawat sederhana masuk kategori baik sekali ada sebanyak 3 sekolah yaitu SD N 3 Ketanggungan dengan persentase sebesar $100 \%$, SD N 4 Ketanggungan dengan persentase sebesar $100 \%$, dan SD $\mathrm{N} 9$ Ketanggungan dengan persentase sebesar $100 \%$. Hal ini terjadi karena sekolah-sekolah tersebut kondisi KIT IPA SEQIP yang lengkap dan memadai tidak banyak yang rusak, kondisinya masih lengkap karena perawatannya yang baik dan tempat penyimpanannya yang baik.

Berdasarkan persentase kondisi KIT IPA pesawat sederhana dan di dukung oleh hasil wawancara terhadap guru mata pelajaran Ilmu Pengetahuan Alam tentang kondisi KIT IPA di masing-masing sekolah sudah baik dan layak digunakan.

c. Cara Pemanfaatan KIT IPA Pesawat Sederhana Kelas V

Bukan hanya ketersediaan dan kondisi KIT IPA saja yang harus baik, cara pemanfaatannya juga harus di manfaatkan dengan baik. Cara pemanfaatan KIT IPA yang baik akan dapat membuat tercapainya tujuan pembelajaran dalam kegiatan belajar mengajar [25].
Dilihat dari hasil penelitian yang peneliti lakukan, disimpulkan bahwa rata-rata persentase cara pemanfaatan KIT IPA pada proses pelaksanaan pembelajaran Ilmu Pengetahuan Alam materi pesawat sedehana kelas V Sekolah Dasar Negeri terakreditasi A se-Kecamatan Ketanggungan adalah sebesar $24 \%$ dengan kategori kurang sekali.

Dari ke-3 Sekolah yang di teliti, maka sekolah yang masuk kategori kurang dalam cara pemanfaatan KIT IPA pesawat sederhana yaitu SD $\mathrm{N} 3$ Ketanggungan dengan persentase sebesar 36\%, SD N 4 Ketanggungan dengan persentase sebesar 18\%, dan SD N 9 Ketanggungan dengan persentase sebesar $18 \%$. Hal ini terjadi karena sekolah tersebut sangat kurang dalam pemanfaatan KIT IPA serta guru yang tidak maksimal dalam pemanfaatan KIT IPA dalam pembelajaran. Guru hanya menggunakan alat-alat sederhana yang mudah di jumpai dalam kehidupan sehari-hari sebagai media dalam pembelajaran.

Berdasarkan persentase di atas dan didukung dari hasil wawancara terhadap guru mata pelajaran Ilmu Pengetahuan Alam bahwa KIT IPA materi pesawat sederhana tersebut kurang dimanfaatkan dalam kegiatan pembelajaran di karenakan adanya kesulitan dalam merakit KIT tersebut.

\section{SIMPULAN}


Jurnal KONTEKSTUAL, Volume 1, No. 1, Agustus 2019, pp. 7-17

Berdasarkan hasil penelitian, peneliti membuat kesimpulan sebagai berikut:

1. Ketersediaan dan kondisi KIT IPA dalam pembelajaran Ilmu Pengetahuan Alam merupakan salah satu sarana dan fasilitas pendukung dalam pembelajaran Ilmu Pengetahuan Alam. Pemanfaatan KIT IPA dalam pembelajaran Ilmu Pengetahuan Alam sangat membantu guru dalam proses pembelajaran.

2. Adanya ketersediaan KIT IPA di Sekolah Dasar Negeri terakreditasi A se-Kecamatan Ketanggungan sudah tersedia sangat baik dengan hasil persentasenya sebesar 98,3\%. Dari ke-3 Sekolah tersebut yang ketersediaan KIT IPA pesawat sederhana masuk kategori baik sekali yaitu SD Negeri 9 dengan persentase sebesar 95\%, kemudian SD Negeri 3 dan SD Negeri 4 dengan persentase sebesar $100 \%$.

3. Kondisi KIT IPA di Sekolah Dasar Negeri Terakreditasi A seKecamatan Ketanggungan dikatakan layak dengan hasil persentasenya sebesar 100\%. Dari ke-3 sekolah yang kondisi KIT IPA pesawat sederhana masuk kategori baik sekali yaitu SD Negeri 3, SD Negeri 4 dan SD Negeri 9 dengan persentase sebesar $100 \%$.

4. Selain itu, pemanfaatan KIT IPA dalam pembelajaran Ilmu Pengetahuan Alam materi pesawat sederhana pada siswa kelas $\mathrm{V}$ Sekolah Dasar Negeri Terakreditasi A se-Kecamatan Ketanggungan di katakan sangat kurang dalam memanfaatkan dengan persentase sebesar 24\%. Dari ke-3 sekolah yang di teliti, yang masuk kategori kurang dalam cara pemanfaatan KIT IPA pesawat sederhana yaitu SD Negeri 3 dengan persentase sebesar $36 \%$, SD Negeri 9 dengan persentase sebesar
18\%, dan SD Negeri 4 dengan persentase sebesar $18 \%$.

\section{Daftar Pustaka}

[1] Ali, Muhammad, 2005, Metode Kependidikan, Prosuder, dan Strategi Pembelajaran. Bandung: Angkasa.

[2] Aqib, Zainal, 2013, Model-model, Media dan Strategi Pembelajaran Kontekstual (Inovatif). Bandung: Yrama Widya.

[3] Wahyudin, Dinn, 2008, Pengantar Pendidikan. Jakarta: Universitas Terbuka.

[4] Djahiri, Kosasih, 2007, Kapita Selekta Pembelajaran Pembaharuan Paradigma PKNPIPS-PAI. Bandung: Sekolah Pasca Sarjana UPI.

[5] Sufyarma, M, 2004, Kapita Selekta Manajeman Pendidikan. Bandung: Alfabeta.

[6] Departemen Pendidikan Nasional, 2006, Standar Isi. Jakarta: Depdiknas.

[7] Poerwanti, Endang, 2008, Asesmen Pembelajaran SD. Jakarta: Direktorat Jendral Pendidikan Tinggi.

[8] Arikunto, Suharsimi, 2006, Penelitian Tindakan Kelas. Jakarta: Bumi Aksara.

[9] Rustaman, N, 2009, Strategi Belajar Mengajar Biologi. Bandung: FPMIPA UPI.

[10] Machin, A, 2014, Implementasi Pendekatan Saintifik, Penanaman Karakter, dan Konservasi pada 
Jurnal KONTEKSTUAL

Volume 01, No. 1, Agustus 2019, pp. 1-6

Pembelajaran IPA. Bandung: Rineka Cipta.

[11] Hasanah, N, 2011, Pengembangan RPP dan LKS IPA Terintegrasi. Jakarta: Raja Grafindo Persada.

[12] Cahyani, R, 2014, Kemampuan Kognisi dan Kerja Ilmiah IPA. Bandung: Rineka Cipta.

[13] Trowbridge, Bybee, 1990, Becoming A Secondary School Sciece Teacher. Ohio: Merril Publishing Company.

[14] Anggoro, Toha, 2008, Metode Penelitian. Jakarta: Universitas Terbuka.

[15] Sugiyono, 2015, Metode Penelitian Kuantitatif, Kualitatif, dan $R \& D$, Bandung: Alfabeta.

[16] Ali, Muhammad, 2005, Metode Kependidikan, Prosuder, dan Strategi Pembelajaran. Bandung: Angkasa.

[17] Suryanto, Adi, 2008, Evaluasi Pembelajaran di SD. Jakarta: Universitas Terbuka.

[18] Rohmadi, 2011, Penelitian Tindakan Kelas. Semarang: Universitas Negeri Semarang.

[19] Anggoro, Toha, 2008, Metode Penelitian. Jakarta: Universitas Terbuka.
[20] Rusman, 2012, Model-Model Pembelajaran. Jakarta: Raja Grafindo Persada.

[21] Anitah, Sri, 2009, Strategi Pembelajaran di SD. Jakarta: Universitas Terbuka.

[22] Sugiyono, 2015, Metode Penelitian Kuantitatif, Kualitatif, dan $R \& D$, Bandung: Alfabeta.

[23] Fajar, A M, 2001, Platform Reformasi Pendidikan dan Pengembangan Sumber Daya Manusia. Jakarta: Logos Wacana Ilmu.

[24] Ibrahim, M, 2005, Seri Pembelajaran Inovatif: Asesmen Berkelanjutan, Konsep Dasar, Tahapan pengembangan, dan Contoh Materi. Surabaya: UNESA University Press.

[25] Utomo, Pristiadi, 2008, Pembinaan dan Pengembangan Profesi Guru. Jakarta: Direktorat Jenderal Peningkatan Mutu Pendidik dan Tenaga Kependidikan. 